Мілімко Л. В., Крейцман Д. В.

УДК 346.232:336.61(045)

Л. В. Мілімко,

кандидат юридичних наук, доцент

ORCID ID: https://orcid.org/0000-0001-5821-5862

Д. В. Крейцман,

здобувач вищої освіти другого (магістерського) рівня

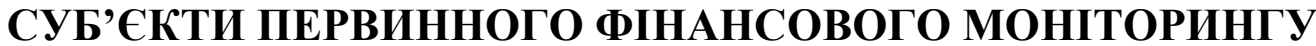 (ГОСПОДАРСЬКО-ПРАВОВИЙ АСПЕКТ)
}

\author{
Національний авіаційний університет \\ проспект Любомира Гузара, 1, 03680, Київ, Україна \\ E-mails: larisa_milimko@ukr.net, christmann.kmk@gmail.com
}

\begin{abstract}
Мета: дати характеристику правовому регулюванню фінансового моніторингу $i$ суб'єктам первинного фінансового моніторингу, як окремим учасникам господарсько-правових відносин; виявити проблеми та внести пропозииї щуодо удосконалення правового регулювання їхньої діяльності. Методи: дослідження проведено з використанням таких методів як аналіз, синтез, порівняння. Результати: дана характеристика правовому регулюванню фінансового моніторингу, визначені суб'єкти господарювання, на яких покладено обов'язок із виконання первинного фінансового моніторингу, сформульовано пропозииії до Закону України «Про запобігання та протидію легалізації (відмиванню) доходів, одержаних злочинним шляхом, фінансуванню тероризму та фінансуванню розповсюдження зброї масового знищення». Обговорення: проблеми правового регулювання фінансового моніторингу $i$ розширення кола суб'єктів первинного фінансового моніторингу.
\end{abstract}

Ключові слова: фінансовий моніторинг; відмивання грошей; фінансування тероризму; ризикорієнтований підхід; кіниевий бенефіціарний власник; належна перевірка.

Постановка проблеми та їі актуальність. Проблема корупції серед учасників господарських відносин і посадових осіб держави на всіх рівнях існувала з часів здобуття Україною незалежності і залишається актуальною сьогодні. Вона створює неабиякі перешкоди для успішного розвитку економіки країни, окремих її галузей, і суспільства в цілому; не дозволяє належним чином використовувати існуючий ресурсний і людський потенціал для поліпшення рівня життя і добробуту більшості населення України.

3 метою протидії легалізації (відмиванню) доходів, одержаних злочинним шляхом, фінансуванню тероризму та фінансуванню розповсюдження зброї масового знищення в Україні створена відповідна нормативноправова база, яка протягом 18 років змінювалась і еволюціонувала.
Безумовно відповідні заходи дозволили наблизити національну правову базу із запобігання відмиванню злочинних доходів до стандартів $\mathrm{EC}$, створити державну систему моніторингу за фінансовими операціями, які потенційно можуть бути пов'язаними 3 небезпечними злочинами. Особливістю цієї системи є те, що наглядові і безпекові функції відповідно до чинного законодавства покладені не лише на державні органи правопорядку, фіскальну службу або інші інституції контролю з особливим статусом, a на звичайних учасників господарськоправових відносин: юридичних осіб (в першу чергу - банки), фізичних осіб - підприємців, фізичних осіб, що провадять незалежну професійну діяльність (приватних нотаріусів, адвокатів, аудиторів, бухгалтерів), до компетенції яких належить здійснення господарськоправових операцій 3 майном. Непоодинокі 
випадки, коли такі операції мають ознаки кримінальних правопорушень. Такі суб'єкти господарювання відносяться до суб' єктів первинного фінансового моніторингу.

Проте, незважаючи на існування відповідної системи моніторингу, фактично відтік капіталів 3 України до інших економічних територій суттєво не зменшився, а доходи, одержані злочинним шляхом, вільно і безперешкодно інвестуються в об'єкти нерухомості, що свідчить про недостатню ефективність існуючої системи фінансового моніторингу.

Саме проблемі ефективності функціонування системи фінансового моніторингу і недостатнього рівня залучення суб'єктів первинного фінансового моніторингу присвячена дана стаття.

Аналіз останніх досліджень і публікацій. Означена проблематика $\epsilon$ предметом дослідження як практичних працівників, так і науковців. Окремі питання фінансового моніторингу досліджували такі вчені як С. Арбузов, Ю. Колобов, В. Міщенко, С. Науменкова, А. Чубенко, М. Лошицький, Д. Павлов, С.Бичкова, О. Юнін та ін. Однак, на сьогодні бракує теоретичних досліджень щодо якісної імплементації Директив СC і рекомендацій MONEYVAL щодо боротьби 3 відмиванням грошей, в українське правове поле.

Мета статті полягає у висвітленні проблемних питань, що виникають на практиці в процесі здійснення фінансового моніторингу в частині належного виконання обов'язків суб'єктами первинного фінансового моніторингу, та розробці пропозицій щодо шляхів їх вирішення.

Виклад основного матеріалу. До легалізації (відмивання) доходів, одержаних злочинним шляхом, належать будь-які дії, пов'язані зі вчиненням фінансової операції чи правочину з доходами, одержаними злочинним шляхом, а також вчиненням дій, спрямованих на приховання чи маскування незаконного походження таких доходів, чи володіння ними, прав на такі доходи, джерел їх походження, місцезнаходження, переміщення, зміну їх форми (перетворення), а так само набуттям, володінням або використанням доходів, одержаних злочинним шляхом, відповідно до ст. 5 Закону України «Про запобігання та протидію легалізації (відмиванню) доходів, одержаних злочинним шляхом, фінансуванню тероризму та фінансуванню розповсюдження зброї масового знищення» від 06.12.2019 р. № 361-IX [1].

Як визначено в п. 1-66 ст. 1 цього Закону: «фінансовий моніторинг - це сукупність заходів, що вживаються суб'єктами фінансового моніторингу у сфері запобігання та протидії легалізації (відмиванню) доходів, одержаних злочинним шляхом, фінансуванню тероризму та фінансуванню розповсюдження зброї масового знищення».

Відносини, що виникають у сфері запобігання та протидії легалізації (відмиванню) доходів, одержаних злочинним шляхом, фінансуванню тероризму та фінансуванню розповсюдження зброї масового знищення, регулюються Конституцією України [2], міжнародними договорами, згоду на обов'язковість яких надано Верховною Радою України, Законом України «Про запобігання та протидію легалізації (відмиванню) доходів, одержаних злочинним шляхом, фінансуванню тероризму та фінансуванню розповсюдження зброї масового знищення» № 361-IX від 06.12.2019 р. [1] та іншими законами, а також прийнятими на їх виконання нормативно-правовими актами.

Варто зазначити, що закон № 361-IX є вже четвертою редакцією Базового Закону з протидії відмиванню доходів, починаючи 32002 року. Цей закон спрямований на: продовження заходів щодо дотримання настанов FATF; імплементацію в національне законодавство, що регулює фінансові операції суб'єктів господарювання, вимог Директиви Європейського Парламенту та Ради Про запобігання використанню фінансової системи для цілей відмивання грошей або фінансування тероризму № (EU)2015/849 від 20.05.2015 р. [3] та Регламенту Свропейського Парламенту та Ради Про інформацію, що супроводжує грошові перекази № (EU)2015/847 від 20.05.2015 p. [4], які обов'язкові для застосування членами Європейського Союзу та державами, що збираються приєднатися до ЄС; наближення національної нормативно-правової бази до вимог положень, що були узгоджені під час 5-го раунду взаємної оцінки України у сфері протидії відмиванню коштів та фінансуванню тероризму на 55-му Пленарному засіданні MONEYVAL. 
До новел у поточній редакції закону належить, передусім збільшення кола суб'єктів первинного фінансового моніторингу (далі СПФМ), які провадять окремі види господарської діяльності (переважно ті, що регулюються: $\S 4$ глави 30, главами 31, 35 Господарського кодексу України [5]).

Статтею 18 Закону № 361-ІХ СПФМ поділені на 5 груп залежно від того, яким суб'єктом державного фінансового моніторингу вони регулюються:

1) банки, страховики, інші організації які надають фінансові послуги - підзвітні НБУ;

2) біржі, управителі фондів фінансування будівництва/операцій 3 нерухомістю, професійні учасники фондового ринку - підзвітні НКЦПФР;

3) аудитори, бухгалтери, консультанти, ріелтори, продавці дорогоцінних металів, організатори лотерей - підзвітні безпосередньо Державній службі фінансового моніторингу;

4) адвокати, нотаріуси, надавачі юридичних послуг - підзвітні Міністерству юстиції України;

5) постачальники послуг, пов'язаних із обігом віртуальних активів - підзвітні Міністерству цифрової трансформації України.

Крім того, законом встановлюється більш досконала процедура визначення кінцевого бенефіціарного власника (контролера), обов'язок зі встановлення суб'єктами господарювання якого визначений статтею 64-1 ГК України [5].

Серед інших новацій, також, застосування щодо виявлення підозрілих фінансових операцій ризик-орієнтованого підходу і проведення процедури належної перевірки контрагента.

Ще, закон № 361-IX передбачає внесення змін до Кримінального [6] та Кримінального процесуального [7] кодексів України 3 питань, що стосуються кримінальної відповідальності за легалізацію (відмивання) майна, одержаного злочинним шляхом, використання коштів, здобутих від незаконного обігу наркотичних засобів, процедурних питань стосовно замороження активів, включення суб'єктів господарювання до санкційних переліків, тощо.

Тож, до фінансових операцій, що підлягають фінансовому моніторингу, належать порогові фінансові операції і підозрілі фінансові операції. Відповідно до ст. 20 Закону України № 361-IX, фінансові операції є пороговими, якщо сума, на яку здійснюється кожна із них, дорівнює чи перевищує 400 тисяч гривень (для суб'єктів господарювання, які проводять лотереї та/або азартні ігри, - 55 тисяч гривень) або дорівнює чи перевищує еквівалент цієї суми в іноземній валюті, банківських металах, інших активах, за наявності однієї або більше таких ознак:

- здійснення фінансових операцій у разі, якщо хоча б одна із сторін - учасників має відповідну реєстрацію, місце проживання чи місцезнаходження в державі, або банківський рахунок в такій державі, що не виконує рекомендації міжнародних організацій, задіяних у сфері боротьби 3 легалізацією (відмиванням) доходів, одержаних злочинним шляхом, фінансуванням тероризму чи фінансуванням розповсюдження зброї масового знищення;

- фінансові операції політично значущих осіб, членів їх сім'ї та інших пов'язаних 3 ними;

- фінансові операції із переказу коштів за кордон;

- фінансові операції з готівкою (внесення, переказ, отримання коштів).

Підозрілими можуть бути визначені фінансові операції або спроба їх проведення незалежно від суми, на яку вони проводяться [1].

Згідно Звіту Державної служби фінансового моніторингу за 2019 рік [8] найбільш активними в системі звітування, в розрізі СПФМ, є банківські установи, які надсилають переважну більшість повідомлень про фінансові операції, що підлягають фінансовому моніторингу. Протягом 2019 року від банківських установ взято на облік 99,04\% від загальної кількості повідомлень про фінансові операції. В абсолютному виразі кількість повідомлень про підозри у причетності до відмивання коштів або фінансування тероризму склала 11327040 від банківських установ і 110095 від небанківських установ. Серед небанківських установ найбільш активними у поданні повідомлень $є$ професійні учасники ринку цінних паперів і страхові установи. Питома вага таких повідомлень у загальному обсязі взятих на облік повідомлень про фінансові операції, що надійшли до Держфінмоніторингу від небанківського сектору склала $46,51 \%$ i $40,40 \%$ відповідно. Таким чином, частка повідомлень від інших, встановлених частиною 2 статті 6 Закону № 361-IX, СПФМ настільки мала, що можна стверджувати про відсутність си- 
стемного підходу до залучення вказаних суб'єктів до системи фінансового моніторингу. Показовою $є$ участь нотаріусів: за рік серед 11437374 повідомлень, отриманих Державною службою фінансового моніторингу, від нотаріусів надійшло всього 11 повідомлень.

Незважаючи на те, що статтею 8 Закону № 361-IX визначено завдання, обов'язки та права суб'єкта первинного фінансового моніторингу, а статтями 32, 33, 34 встановлена відповідальність СПФМ за порушення вимог законодавства, яка передбачає досить жорсткі санкції у вигляді великих штрафів і позбавлення ліцензії на здійснення діяльності, більшість цих норм стосується банків і учасників ринку фінансових послуг; для СПФМ 3-ї і 4-ї груп, таких як аудитори, бухгалтери, ріелтори, адвокати, нотаріуси, обов'язкової вимоги стати на облік в державному органі 3 функцією фінансового моніторингу немає. Відповідальність цих суб' єктів за непостановку на відповідний облік не передбачена, і вони цілком законно можуть здійснювати свою професійну діяльність без такої постановки. На практиці, норми встановлені у частинах 1.1 та 1.2 статті 10 Закону № 361-IX абсолютно не працюють, а роль спеціально визначених суб'єктів фінансового моніторингу зводиться до нуля.

Правочини щодо об'єктів нерухомості і майнових прав на них фактично знаходяться поза фінансовим моніторингом до моменту здійснення розрахунків через установу банку (хоча в багатьох випадках і банками застосовують механізми і схеми для усунення $з$ фінансової операції ознак порогової і непідпадання іiі під фінансовий моніторинг). Під час здійснення операцій з нерухомістю, навіть за високого ступеня сумніву щодо легальності походження джерела грошових коштів клієнта, або утаємниченості особи кінцевого бенефіціарного власника, існує надзвичайно мала ймовірність, що ріелтор або нотаріус, який обслуговує операцію, 3 метою виконання вимог Закону України № 361-IX повідомить про підозрілу операцію у відповідний державний орган 3 фінансового моніторингу. В найкращому випадку він діятиме відповідно до ст. 15 закону № 361-IX, а саме - відмовиться від встановлення ділових відносин із підозрілим клієнтом.
Нотаріуси, ріелтори, надавачі бухгалтерських і юридичних послуг не зацікавлені, не вмотивовані, недостатньо обізнані про свій обов’ язок здійснювати свої функції щодо фінансового моніторингу, оскільки законом чітко не встановлено їхній порядок взаємодії з державним суб'єктом фінансового моніторингу і порядок звітування до нього, на відміну від порядку взаємодії банків із НБУ.

Зрозуміло, що визначені категорії СПФМ було додано в новій редакції Закону України «Про запобігання та протидію легалізації (відмиванню) доходів, одержаних злочинним шляхом, фінансуванню тероризму та фінансуванню розповсюдження зброї масового знищення» 3 метою його (закону) відповідності Директиві ЄC, однак докладного, вичерпного і зрозумілого інструментарію для залучення нового кола осіб до системи фінансового моніторингу держави створено не було. На електронному ресурсі Державної служби фінансового моніторингу України містяться Рекомендації щодо подання 3 28 квітня 2020 року небанківськими установами до Держфінмоніторингу інформації про фінансові операції та щодо постановки на облік СПФМ [9], які в свою чергу посилаються на Порядок подання інформації для взяття на облік (зняття з обліку) суб'єктів первинного фінансового моніторингу, виявлення та реєстрації, а також подання суб'єктами первинного фінансового моніторингу Державній службі фінансового моніторингу інформації про фінансові операції, що підлягають фінансовому моніторингу, іншої інформації, що може бути пов'язана 3 легалізацією (відмиванням) доходів, одержаних злочинним шляхом, або фінансуванням тероризму чи фінансуванням розповсюдження зброї масового знищення [10], затверджений постановою Кабінету Міністрів України від 5 серпня 2015 р. № 552, який є застарілим, оскільки досі не актуалізований зі змінами, що містяться в чинній редакції базового закону «Про запобігання та протидію легалізації (відмиванню) доходів, одержаних злочинним шляхом, фінансуванню тероризму та фінансуванню розповсюдження зброї масового знищення» від 06 грудня 2019 р.

Такий стан нормативно-правових актів щодо фінансового моніторингу унеможливлює належне виконання завдань і цілей державної 
політики із запобігання та протидії легалізації (відмиванню) доходів, одержаних злочинним шляхом, фінансуванню тероризму та фінансуванню розповсюдження зброї масового знищення.

Висновки. Отже, підводячи підсумок викладеному вище слід зазначити, що впровадження рекомендацій FATF і MONEYVAL, імплементація в законодавство України вимог Директив ЄC у сфері протидії відмиванню коштів та фінансуванню тероризму $є$ логічними і важливими заходами у вітчизняній законотворчості, проте існує низка серйозних недоліків і недопрацювань у базовому законі щодо протидії відмиванню коштів та фінансуванню тероризму i підзаконних актах, які унеможливлюють належне і ефективне функціонування державної системи фінансового моніторингу.

Так, потребують удосконалення норми, закріплені п. 2.1 ст. 8, п. 1 ст. 36 Закону «Про запобігання та протидію легалізації (відмиванню) доходів, одержаних злочинним шляхом, фінансуванню тероризму та фінансуванню розповсюдження зброї масового знищення» шляхом їх деталізації з метою уникнення неоднозначного трактування суб' єктами первинного фінансового моніторингу. Крім того, мають бути внесені зміни до «Порядку подання інформації для взяття на облік (зняття 3 обліку) суб'єктів первинного фінансового моніторингу, виявлення та реєстрації, а також подання суб'єктами первинного фінансового моніторингу Державній службі фінансового моніторингу інформації про фінансові операції, що підлягають фінансовому моніторингу, іншої інформації, що може бути пов'язана 3 легалізацією (відмиванням) доходів, одержаних злочинним шляхом, або фінансуванням тероризму чи фінансуванням розповсюдження зброї масового знищення», затвердженого постановою Кабінету Міністрів України від 5 серпня 2015 р. № 552, які 6 відповідали вимогам Закону України № 361-IX від 06 грудня 2019 р. Для досягнення належної ефективності від застосування, зазначені правові акти повинні мати не факультативний і рекомендаційний характер, а бути максимально конкретизованими, однозначними і бути обов'язковими для виконання для всіх визначених суб'єктів фінансового моніторингу.
Судові спори щодо неправомірності застосування суб'єктами первинного фінансового моніторингу доступних для впровадження ними санкцій по відношенню до суб'єктів господарювання, чиї права вони порушили (заморозили активи, не виконали фінансову операцію, не виконали обумовлені в договорі господарські зобов'язання), мають розглядатися в порядку господарського судочинства.

\section{Jimepamypa}

1. Про запобігання та протидію легалізації (відмиванню) доходів, одержаних злочинним шляхом, фінансуванню тероризму та фінансуванню розповсюдження зброї масового знищення: Закон України від 06 груд. 2019 р. № 361-IX. URL: https://zakon.rada.gov.ua/laws/ show/361-20 (дата звернення: 07.11.2020).

2. Конституція України від 28 чер. 1996 р. № 254к/96-BP. URL: https://zakon. rada.gov.ua/ laws/show/254\%D0\%BA/96-\%D0\%B2\%D1\%80 (дата звернення: 07.11.2020).

3. Про запобігання використанню фінансової системи для цілей відмивання грошей або фінансування тероризму: Директива Європейського Парламенту та Ради від 20 трав. 2015 p. № (EU)2015/849. URL: https://eurlex.europa.eu/ legal-content/EN/TXT/?uri=celex \% 3A32015L0849 (дата звернення: 07.11.2020).

4. Про інформацію, що супроводжує грошові перекази: Регламент Європейського Парламенту та Ради від 20 трав. 2015 р. № (EU)2015/847. URL: https://eur-lex.europa.eu/legal-content/EN/ TXT/?uri=celex\%3A32015R0847 (дата звернення: 07.11.2020).

5. Господарський кодекс України від 16 січ. 2003 p. № 436-IV. URL: https://zakon.rada.gov.ua/ laws/show/436-15 (дата звернення: 07.11.2020).

6. Кримінальний кодекс України від 05 квіт. 2001 p. № 2341-III. URL: https://zakon.rada.gov. ua/ laws/ show/ 2341-14 (дата звернення: 07.11.2020).

7. Кримінальний процесуальний кодекс України від 13 квіт. 2012 р. № 4651-VI. URL: https://zakon.rada.gov.ua/laws/show/4651-17 (дата звернення: 07.11.2020).

8. Звіт Державної служби фінансового моніторингу України за 2019 рік. Київ, 2020. C. 15-17. URL: https://www.sdfm.gov.ua/ assets/ 
userfiles/ 0350/ zvity/ zvit2019ua.pdf (дата звернення 07.11.2020).

9. Рекомендації щодо подання 328 квітня 2020 року небанківськими установами до Держфінмоніторингу інформації про фінансові операції та щодо постановки на облік СПФМ. URL: https://www.sdfm.gov.ua/pages/ finansoviimonitorint/tehnologi/dlja-nebankivskih-ustanov/ rekomendacziji-shhodo-podannya-z-28-kvitnya2020-roku-bankami-do-derzhfinmonitoringuinformacziji-pro-finansovi-operacziji.html (дата звернення 08.11.2020).

10. Деякі питання організації фінансового моніторингу: Постанова Кабінету Міністрів України від 05 cep. 2015 p. № 552. URL: https://zakon. rada.gov.ua/laws/show/552-2015-\% D0\%BF (дата звернення 08.11.2020).

\section{References}

1. Pro zapobihann'a ta protydiju lehalizacii' (vidmyvann'u) dohodiv, oderzhanyh zlochynnym shlyahom, finansuvann'u teroryzmu ta finansuvann'u rozpovs'udzhenn'a zbroi' masovoho znyshchenn'a: Zakon Ukrai'ny vid 06 hrud. 2019 r. № 361-IX. URL: https://zakon.rada.gov.ua/ laws/show/361-20 (data zvernenn'a: 07.11.2020).

2. Konstytucija Ukrai'ny vid 28 cher. $1996 \mathrm{r}$. № 254k/96-VR. URL: https://zakon.rada.gov.ua/ laws/show/254 (data zvernenn'a: 07.11.2020).

3. Pro zapobihann'a vykorystann'u finansovoji systemy dl'a cilej vidmyvann'a hroshej abo finansuvann'a teroryzmu: Dyrektyva Europejs'koho Parlamentu ta Rady vid 20 trav. $2015 \mathrm{r}$. № (EU)2015/849. URL:https://eur-lex.europa.eu/ legal-content/EN/TXT/?uri=celex\%3A32015L0849 (data zvernenn'a: 07.11.2020).

4. Pro informaciju, scho suprovodjuje hroshovi perekazy: Reglament Europejs'koho Parlamentu ta Rady vid 20 trav. 2015 r. № (EU)2015/847. URL: https://eur-lex.europa.eu/legal-content/ EN/ TXT/ ?
uri=celex\%3A32015R0847 (data zvernenn'a: 07.11.2020).

5. Hospodars'kyj kodeks Ukrai'ny vid 16 sich. 2003 r. № 436-IV. URL: https://zakon.rada.gov. ua/ laws/show/436-15 (data zvernenn'a: 07.11.2020).

6. Kryminal'nyj kodeks Ukrai'ny vid 05 kvit. 2001 r. № 2341-III. URL: https://zakon.rada. gov.ua/laws/show/2341-14 (data zvernenn'a: 07.11.2020).

7. Kryminal'nyj procesual'nyj kodeks Ukrai'ny vid 13 kvit. 2012 p. № 4651-VI. URL: https://zakon.rada.gov.ua/laws/show/4651-17 (data zvernenn'a: 07.11.2020).

8. Zvit Derzhavnoii' sluzhby finansovoho monitorynhu Ukrai'ny za 2019 rik. Kyiv, 2020. S. 15-17. URL:https://www.sdfm.gov.ua/assets/userfiles/035 0/zvity/ zvit2019ua.pdf (data zvernenn'a 07.11.2020).

9. Rekomendaciji schodo podann'a z 28 kvitn'a 2020 roku nebankivs'kymy ustanovamy do Derzhfinmonitorynhu informaciji pro finansovi operaciji ta schodo postanovky na oblik SPFM. URL: https://www.sdfm.gov.ua/pages/finansoviimonitorint/tehnologi/dlja-nebankivskihustanov/rekomendacziji-shhodo-podannya-z-28kvitnya-2020-roku-bankami-doderzhfinmonitoringu-informacziji-pro-finansovioperacziji.html (data zvernenn'a 08.11.2020).

10. Dejaki pytann'a orhanizaciji finansovoho monitorynhu: Postanova Kabinetu Ministriv Ukrai'ny vid 05 ser. 2015 r. № 552. URL: https://zakon.rada.gov.ua/ laws/show/552-2015\%D0\%BF (data zvernenn'a 08.11.2020). 


\title{
REPORTING ENTITIES IN COMMERCIAL LAW
}

\author{
National Aviation University \\ Liubomyra Huzara Avenue, 1, 03680, Kyiv, Ukraine \\ E-mails: larisa_milimko@ukr.net, christmann.kmk@gmail.com
}

Purpose: to characterize the legal regulation of the financial monitoring and the reporting entities as individual participants in commercial relations; to identify problems and make suggestions for improving the legal regulation of their activities. Methods: the study was conducted using methods such as analysis, synthesis, comparison. Results: the characteristic is given to the legal regulation of the financial monitoring; business entities, that are responsible for performing primary financial monitoring, are identified; the proposals are formulated to the Law of Ukraine «On prevention and counteraction to proceeds from crime legalization (laundering), to financing of terrorism and to financing of mass destruction weapons proliferation».

The problem of corruption among the participants of economic relations and the government officials at all the levels has existed since Ukraine's independence and this problem remains still relevant. It hinders the successful development of the country's economy, it's individual industries, and society as a whole; it does not allow the proper use of the existing resource and human potentials to improve the living standards and well-being of population majority of Ukraine.

An appropriate regulatory framework has been created in Ukraine for the purpose of prevention and counteraction to proceeds from crime legalization (laundering), to financing of terrorism and to financing of mass destruction weapons proliferation. This regulatory framework has been changing and evolving for over 18 years.

Certainly, the relevant measures have brought the national legal framework for the prevention of money laundering closer to EU standards, and have created a state system for financial transactions monitoring that could potentially be associated with the dangerous crimes. The peculiarity of this system is that the supervisory and security functions in accordance with current legislation are entrusted not only to public law enforcement agencies, fiscal service or other control institutions with some special status, but also to ordinary participants in economic relations: legal entities (primarily banks)), individual entrepreneurs, individuals engaged in independent professional activities (private notaries, lawyers, auditors, accountants), whose competence includes the implementation of economic and legal transactions with property that may have signs of criminal origin. Entities endowed with these powers are the reporting entities.

However, despite the existence of an appropriate monitoring system, in fact, the Ukraine's capital outflow to other economic territories has not significantly decreased, also proceeds from crime are freely and unhinderedly invested in real estate. This indicates an efficiency lack of the existing financial monitoring system.

This article is devoted to the problem of the financial monitoring system efficiency, and to insufficient level of reporting entities involvement.

Keywords: financial monitoring; money laundering; terrorism financing; risk-oriented approach; true beneficial owner; proper verification. 